\title{
Evaluation of Football Coach Competence of Early Age in Football Schools
}

\author{
Ujang Rohman ${ }^{1}$, Hari Setijono ${ }^{2}$ \\ Department of Sport Science, Postgraduate Program \\ State University of Surabaya \\ Surabaya, Indonesia \\ jankroh64@gmail.com ${ }^{1}$, harisetiono@yahoo.co.id ${ }^{2}$
}

\begin{abstract}
This study further highlights the competency of football coach of early age. The method used in this research are mixed methods. Based on the analysis of quantitative and qualitative, then the results are : 1. Context Evaluation. Analysis reveals that the variable scores of coach presence in the count of 61.66\% 2. Input Evaluation. Analysis shows score of $53.03 \%$ variable of human resource of the academic coaches. 3. Process Evaluation. Analysis the description of the evaluation process, it includes: competence of development character $59.69 \%$, motivation competence $55.00 \%$,technical competence $53.51 \%$ and competence of games strategy $50.00 \%$. The analysis of SEM through approach Partial Least Square (PLS) is known from the value of $R$-square $\left(R^{2}\right)$, for character development competence $\left(X_{1}\right) 0.7549$, competence of motivation $\left(X_{2}\right) 0.6844$, technical competence $\left(X_{3}\right) \quad 0.7805$ and competency games strategy $\left(X_{4}\right)$ 0.7572. Shows that all indicators represent variables of coach competencies which describe the significant influence, that the competence of football coach of early age has relevance. 4. Product Evaluation. The coach competency formula is conceptually divided into three main parts, it can be said that the standard of football coach competence of early age the capacity of attitude (affective), knowledge (cognitive), and skills (psychomotor).
\end{abstract}

Keywords — competence, football coach an early age

\section{INTRODUCTION}

A coach is one of the indicator of success of the athletes to reach optimal performance, so when viewed from the achievements of Indonesian football team over the last few years in most of the official multievent matches between countries, it is found out that it has not achieved optimum performance. Indonesian football teams in Southeast Asia from 1996 to 2004 had never succeeded in reaching the Tiger Cup champions. Then in 2007 until now, since the Tiger Cup turned into AFF Suzuki Cup (Asean Football Federation Cup) Indonesian football team has never succeeded in reaching the champions. During the participation of Indonesian football teams at the Association of Southeast Asian Nations championship, Indonesia's highest achievement only reached second place in 2000, 2002, 2004 and 2010. Likewise in the event of SEA Games SEA Games ( South East Asian Games) since 1977 until now for the sport of football, Indonesia only twice became the champion of Sea Games XIV SEA Games to 1987 in Jakarta and Sea Games to XVI 1991 in Manila,
Philippines. Meanwhile, based on FIFA (Federation Internationale de Football Association) World Rangking of Indonesian football team achievement in 2010 is ranked 138, the year 2011 was ranked 129, while in 2012, 2013, and 2014 the overall position of Indonesia was ranked 156, 170 ,and 153 and by 2015 Indonesia was ranked 174th.

The fact mentioned above is that one of the success indicators of athletes' achievement is how the coach can spur optimum performance on trained athletes. Referring to these indicators, a question is raised on how about the competence of football coaches in Indonesia? The answer is that the optimal achievement can be encouraged if the coach has the competence that is reflected in the ability of knowledge, skills and attitude in training. Specific coach competencies have not been standardized in every sport, especially in the sport of football. PSSI Association as the parent organization that oversees the sport of football until now has not issued a provision regarding the competency standards of football coach. To support the competence of coaches in training, PSSI associates currently only issue licensing authority to train a coach, whereas the government agencies, namely the Ministry of Youth and Sports through the National Certification and Accreditation Agency of Sport (BSANK) is more functional to prepare policy formulation and implementation of policies standardization, accreditation, and certification of sports. Similarly, sports experts and practitioners formulate the concept of coach competence more generally for sports. On the basis of several issues that exist in football in Indonesia at this time, the researcher is interested to examine more about the competence of football coaches for early- aged students..That hope has been given by the PSSI chairman Johar Arifin who says, "Football Association of Indonesia (PSSI) will seek to raise the competence of coaches for young children. That is important because right now, the coach for a young age is preferred to that for adults. With the increased competence of coaches for young age, then the young talents will be more emerging. And in ten years, the results of youth coaching will be obvious "(para 5) [1].

Based on the above description which underlies the fact that there has not been optimal football achievement yet in Indonesia, there is a need of attention to study and to investigate fundamentally the competence of coaches. This study aims to find out the competence of coach for early-aged 
students of football school with CIPP evaluation model approach (context, input, process, product). The scope of this research is the emphasis on developing the ability and quality of football coaches for eary-aged students in terms of competence aspects of the coaches. The competence of the coaches to be evaluated consists of components of character development competence, game strategy competence motivation competence, and technical competence [2]. The research question formulations are as follow:

- What is the relevance of the existence of football coach for early-aged students of football school from the context evaluation aspect with the formal legality support of government and related institutions at the football school (SSB)?

- What is the relevance of the HR background of football coach for early-aged students from the input evaluation aspect of the football school (SSB)?

- How is the implementation of the assessment and the relation of the competence of a coach for early-aged sudents from the evaluation aspect of football school (SSB)?

- How is the result of the assessment process of the competence of footbal coach for early-aged students from the aspect of product evaluation that produces the standard formula of competence of football coach for early-aged students in football school (SSB)?

In particular, the results of this study will provide benefits asempirical study based on the competency standards of football coaches for early-aged students in football schools (SSB) which can be used as a basis for developing and revising the competence of coaches which consist of parts of competence that are more specific for early-aged students that ultimately they can generate policy formulation of competency standard of football coach for early-aged students which has legality from acknowledging authorized institution.

\section{LITERATURE REVIEW}

\section{A. The Nature of Evaluation}

The term evaluation is synonymous with judgment, which means the systematic process of collecting, analyzing, and interpretingthe data or information obtained. In general, evaluation as an action or process has at least three main functions: (1) measuring progress, (2) supporting the preparation of the plan, and (3) improving or refining (Soegiyono, 2009, p.7-8 ). From some existing evaluation models, the researcher will discuss the CIPP evaluation model (context, input, process, product) developed by Daniel Stufflebeam.. These four aspects include:

1. Context. The main purpose of the context evaluation is to know the strengths and weaknesses of the evaluator. Evaluators will be able to provide the necessary corrective directions related to support in planning decisions.

2. Input. This evaluation sets the decisions and determines the available resources as an alternative strategic plan to meet the needs of a program. In the input evaluation phase, the evaluator tries to reveal the data source in an effort to achieve the objectives of the evaluation program

3. Process. In the evaluation phase of the process, evaluators can reveal the extent to which the implementation of the program has been implemented in the field and assist in making decisions in implementing the planned program.

4. Product. In the product evaluation phase, this evaluation is conducted with the aim of identifying and assessing the achievement of the outcomes in accordance with the intended program objectives, so that findings can be focused on achieving program objectives to meet the needs of the target group.

\section{B. The Nature of the Coach}

Coach is one of the professions of interest compared to other professions. Many trainers love his profession, although the challenge of his profession when training is very complex, because the task of the coach is not just in the field alone but the coach is also a teacher, father, and friend. According to Setijono (2006), factually the condition of the coach has the background of former athletes and academics. Coaches with ex-athlete backgrounds have advantages in terms of skill mastery, field experience, and experience competing in the sports that he or she is involved in. While the trainers with academic background have the ability in theory, physical exercise, psychology, science and technology, and training programming.

\section{The Nature of Competence}

A competent trainer is a trainer who can deliver his knowledge to a trained athlete, and demonstrate techniques to his athlete, so that the athlete can perform techniques well and correctly. The competencies of the trainer will support the training tasks. The competence of the trainers according to the formulation of the results of the Sporting Seminar of the Office of the Ministry of Cooperative Affairs in 2009 are that at least the trainers must have 11 competencies, Philips devides the components of trainer competence into:1.character development competency,2. game strategy competency, 3.motivation competency and 4.technique competency [2].

Based on the concept, it is that the competence of the trainer is the competence that must be possessed by the trainer consisting of the ability in the competence of character development, motivation competence, competence of match strategy, and technical competence.

\section{SUBJECTS AND METHODS}

The method of this research is mixed method, that is a research method that combines quantitative and qualitative methods to be used jointly in a research activity, so that the data obtained will be more comprehensive, valid, reliable and objective [3]. Combined research method uses sequential model using sequential explanatory design which is evaluated by CIPP evaluation model approach which includes evaluation aspect: context, input, process and product comprehensively.

The research target consists of variables: independent variable, that is the evaluation of competence of trainer and 
dependent variable which is the competence of fooball coach for early-aged students consisting of character competence development variable, competence of game strategy, motivation competence, and technical competence. The study population is the entire SSB coaches who are still actively conducting regular coahing activities and are recorded in the Association of East Java PSSI, while the research sample are football coaches for early-aged students in SSB registered in the Association of District / City (Askab / Askot) PSSI East Java who already have a minimum license D license of coaching under the authority issued by the PSSI Association.

The technique of data collection is using two approaches, namely quantitative and qualitative approaches. The data that become the raw material of research is primary data, that is the data obtained through questionnaires, interviews and observations.

\section{DATA ANALYSIS}

\section{A. Quantitative Data Analysis}

Quantitative data analysis is done by statistical analysis of percentage description $(\mathrm{p}=\mathrm{f} / \mathrm{n} \times 100 \%)$ and Structural Equation Modeling (SEM) analysis with Partial Least Square (PLS) approach. Stages of the model in the PLS which include:

- The structural model or Inner model in PLS describing the relationship between variables. The equation model can be written in the following linear equation: It is the coefficient of the relationship between the $i$-th variable and the j-path variable (path coefficient).

- The model of measurement or outer model in PLS can be defined with each indicator block associated with its variables. The reflective indicator block can be written in equation with the following simple regression: that is the coefficient loading of the variable relationship with the k-indicator being the residual or error of each measurement variable.

- Weight relation, the test value of the evaluation of the structural equation model in SEM PLS which can be known from the value of goodness of fit or R-square value (R2). The results of data processing research uses smart PLS 2.0.

- Inner Model or structural model, outer model or measurement model, and weight relation where the value of the variable can be estimated. The calculation process is done by iteration, where iteration will stop if convergent conditions have been reached.

\section{B. Qualitative Data Analysis}

Qualitative data analysis is obtained from the interview and observation which aims to complement, deepen and strengthen the quantitative data obtained from the questionnaire through data sources. Analysis of qualitative data gathered by interview using interactive model. It can be done through steps consisting of: (1) data reduction, (2) display or presentation of data; And (3) concluding and then verifying.
The interactive data model uses a matrix that starts from; data exposure, which is then grouped and collected (data collection), next reduced (data reduction) in accordance with the form of data, and eventually presented (data display) and verified with other data to find one form of conclusion.

The two data analysis studies are mixed methods using quantitative and qualitative approaches with the subject focusing on coaches for early-aged students and the location of the research is football school located in the PSSI Association of East Java.

\section{RESULTS}

\section{A. Test Instruments}

The results of the development of data collection instruments are in the form of questionnaires, interviews and observations. Furthermore, the research instruments are tried out to respondents and informants as the subject of trial. The result of validity test of instrument item from each component is described. Of the 80 items tested in the validity of the instrument, 25 items declared invalid statements and 55 items of valid statements. Invalid items can be used in actual research.The test results reliability instrument items can be seen in the following table.

Based on the description of each of the above variables, it can be stated that the instrument item has a validity value above 0.44 as many as 55 items and reliability value of all items above 0.60 to 0.70 . This means that the instrument has fulfilled the validity and reliability, so they can be used in research. After the fulfillment of the validity and reliability value of research instruments, the process of data retrieval can be carried out through the stages of the dissemination of questionnaires, interviews and observation.

\section{B. Quantitative and Qualitatif Data Analysis}

Based on the distribution of data collected from 60 respondents, then a quantitative data analysis using CIPP evaluation model is conducted which includes:

\section{1) Context Evaluation}

The results of descriptive analysis on each indicator of the presence of coaches include indicators of Government support of $81.66 \%$, PSSI Association of $70.00 \%$. This gives illustration of the competence of coach which is of relevance to the support of government and related institutions that can be used as the legal basis of public confidence in the coach.

2) Input Evaluation

The results of descriptive analysis on each HR indicator of the Trainers include the indicator of the Coach Education of $75 \%$ at least is the SMA / SMK / MA, the Training Duration of 68.33\% 5-10 years and the Training License of $70.00 \%$ D license contains the understanding that the majority of coaches have the same related expectations of HR Coach.

3) Process Evaluation 
Data distribution shows description of process evaluation of which each competency component of coach consists of the following data:

- The results of descriptive analysis of character development competence indicators include: discipline attitude of $72.22 \%$, fair play of $53.88 \%$, sportsmanship of $50.55 \%$ and mutual respect of $63.33 \%$ implies that the majority of coaches have the same expectations about character development through discipline, fair play, sportsmanship and mutual respect in training.

- The result of descriptive analysis of the answers to the competence indicators of the game strategy include: knowing the strengths and weaknesses of $57.22 \%$, understanding the match strategy of $45.92 \%$ and the match situation of $48.33 \%$ containing the understanding that the majority of trainers have the same expectations about the competence of the game strategy consisting of: weaknesses, understanding the strategy of the game and get to know the situation of the game in playing football.

- The results of descriptive analysis of motivation competence indicator include: confidence of $50.55 \%$, mental matching $53.88 \%$, self esteem and confidence of $53.33 \%$, and a sense of togetherness of $62.50 \%$ contains the understanding that the majority of trainers have the same expectations about motivation competence consisting of confidence, mental compete, self-esteem and confidence and a sense of togetherness during training.

- The results of descriptive analysis of technical competence indicator include: demonstrating technique of $57.77 \%$, correcting the technique error of $55.55 \%$, understanding the ability of the students of $47.22 \%$ contains the understanding that the majority of trainers have the same expectations about technical competence consisting of skills modeling techniques, and understanding of students' skills in the learning process of football games.

Description of coach's competence based on Structural Equation Modeling (SEM) analysis with Approach of PLS (Partial Least Square) covers three stages:

\section{1) Measurement Model (Outer Model)}

The two criteria used in the outer model are convergent validity and composite reliability. Convergent validity aims to test the validity of variables done by using confirmatory factor analysis on each variable and composite reliability aims to test the reliability of variables or constructs. The results show the character development competence variables $\left(\mathrm{X}_{1}\right)$ represented by 4 indicators $\left(\mathrm{X}_{1.1}, \mathrm{x} 1.2, \mathrm{X}_{1.3}\right.$ and $\left.\mathrm{X}_{1.4}\right)$, motivation competence variable $\left(\mathrm{X}_{2}\right)$ represented by 4 indicators $\left(\mathrm{X}_{2.1}\right.$., $\mathrm{X} 2.2, \mathrm{X} 2.3$ and $\mathrm{X} 2.4$ ), the technical competence variables (X3) represented by 3 indicators (X3.1, X3.2, and X3.3) and the game strategy competence variable (X4) are represented by 3 indicators X4.1, X4.2, and X4.3) are valid (loading factor value $>0.5)$ and significant with $\mathrm{t}$ arithmetic $>\mathrm{t}$ table (1.96). The results are in the following table 1 .

TABLE 1. THE ANALYSIS RESULT OF

\begin{tabular}{|c|c|c|c|}
\hline \multicolumn{4}{|c|}{ CONVERGENT } \\
\hline Relation. & $\begin{array}{l}\text { Original } \\
\text { Sample }(\mathrm{O})\end{array}$ & $\begin{array}{l}\text { Standard Deviation } \\
\text { (STDEV) }\end{array}$ & $\begin{array}{l}\text { TStatistics } \\
(\mid \text { O/STERR } \mid)\end{array}$ \\
\hline$X_{1.1}<-X_{1}$ & 0.846745 & 0.04286 & 19.756018 \\
\hline$X_{1.2}<-X_{1}$ & 0.57137 & 0.12237 & 4.669205 \\
\hline$X_{1.3}<-X_{1}$ & 0.592829 & 0.134324 & 4.413422 \\
\hline $\mathrm{X}_{1.4}<-\mathrm{X}_{1}$ & 0.702655 & 0.084774 & 8.288606 \\
\hline $\mathbf{X}_{2.1}<-\mathbf{X}_{2}$ & 0.806156 & 0.042816 & 18.828359 \\
\hline $\mathbf{X}_{2.2}<-\mathbf{X}_{2}$ & 0.857744 & 0.04278 & 20.050213 \\
\hline $\mathbf{X}_{2.3}<-\mathbf{X}_{2}$ & 0.671737 & 0.130956 & 5.129496 \\
\hline $\mathbf{X}_{3.1}<-\mathbf{X}_{3}$ & 0.719148 & 0.087859 & 8.185283 \\
\hline $\mathbf{X}_{3.2}<-\mathbf{X}_{3}$ & 0.714683 & 0.080761 & 8.849406 \\
\hline $\mathbf{X}_{3.3}<-\mathbf{X}_{3}$ & 0.770392 & 0.068335 & 11.273761 \\
\hline $\mathbf{X}_{3.4}<-\mathbf{X}_{3}$ & 0.673219 & 0.105215 & 6.398493 \\
\hline$X_{4.1}<-X_{4}$ & 0.813783 & 0.043695 & 18.623971 \\
\hline $\mathbf{X}_{4.2}<-\mathrm{X}_{4}$ & 0.715287 & 0.0921 & 7.766401 \\
\hline$X_{4.3}<-X_{4}$ & 0.831997 & 0.051516 & 16.150331 \\
\hline
\end{tabular}

The results of the composite reliability evaluation show that all the indicators that measure the constructs competence of coach (X) covering the variables of character development competence (X1), motivation competence (X2), technical competence (X3) and game strategy competence $(\mathrm{X} 4)$ are said to have good reliability, with value $>0,7$. The results are in the following table 2 .

TABLE 2. RESULT ANALYSIS OF COMPOSITE RELIABILITY

\begin{tabular}{|l|l|l|}
\hline Variable & \multicolumn{1}{|c|}{ Laten Variable } & $\begin{array}{l}\text { Composite } \\
\text { Reliability }\end{array}$ \\
\hline \multirow{4}{*}{$\begin{array}{l}\text { Competence } \\
\text { Coach }\end{array}$} & $\begin{array}{l}\text { a. } \text { Character } \\
\text { Development }\left(\mathrm{X}_{1}\right)\end{array}$ & 0.777162 \\
\cline { 2 - 3 } & b. Game Strategy $\left(\mathrm{X}_{4}\right)$ & 0.824253 \\
\cline { 2 - 3 } & c. Motivation $\left(\mathrm{X}_{2}\right)$ & 0.811335 \\
\cline { 2 - 3 } & d. Technique $\left(\mathrm{X}_{3}\right)$ & 0.830976 \\
\hline
\end{tabular}

- Structural Model (Inner Model).

Evaluation of the structural model (inner model) is done to know the relationship between variables, namely the relationship between the competence of the coach $(\mathrm{X})$ with the character development competence (X1), motivation competence (X2), technical competence (X3), and game strategy competence (X4). Estimation of structural model of competency relation of coach with competence component of coach variable shows $t$-count value $>$ t-table $(1,96)$ All parameters show significant structural model relationship. The results are in the following table 3 
TABLE 3. ESTIMATION OF COACH COMPETENCE RELATION MODEL

\begin{tabular}{|c|c|c|c|}
\hline Relation. & $\begin{array}{c}\text { Original } \\
\text { Sample (O) }\end{array}$ & $\begin{array}{c}\text { Standard } \\
\text { Deviation } \\
(\text { STDEV) }\end{array}$ & $\begin{array}{c}\text { T Statistics } \\
(\mid \text { O/STERR } \mid)\end{array}$ \\
\hline $\mathbf{X}->\mathbf{X}_{\mathbf{1}}$ & 0.868850 & 0.033335 & 26.064044 \\
\hline $\mathbf{X}->\mathbf{X}_{\mathbf{2}}$ & 0.870154 & 0.032347 & 26.900712 \\
\hline $\mathbf{X}->\mathbf{X}_{\mathbf{3}}$ & 0.827288 & 0.049752 & 16.628261 \\
\hline $\mathbf{X}->\mathbf{X}_{\mathbf{4}}$ & 0.883477 & 0.025850 & 34.177510 \\
\hline
\end{tabular}

The pattern of relation variables can be seen in the figure below.

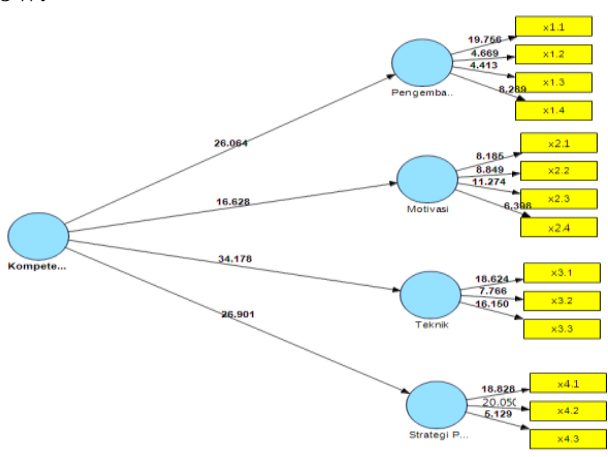

Fig. 1. Variable Relationship of Model Coach Competencies

\section{2) Weight Relation}

The value of evaluation test on structural equation model in SEM through PLS (Partial Least Square) can be known from the value of goodness of fitness or R-square value (R2). The result of analysis obtains R-square (R2) value for model of Character Development Competence (X1), Motivation Competence (X2), TechnicalCompetence (X3) and Game Strategy Competence (X4) in the following table 4.

TABLE 4.EVALUATION TEST OF STRUCTURAL MODEL OF. RSQUARE $\left(\mathrm{R}^{2}\right)$

\begin{tabular}{|l|l|l|}
\hline \multicolumn{1}{|c|}{ Variabel } & \multicolumn{1}{|c|}{ Variabel Laten } & R Square \\
\hline $\begin{array}{l}\text { Coach } \\
\text { Competence } \\
(\mathrm{X})\end{array}$ & Character Developmen $\left(\mathrm{X}_{1}\right)$ & 0.754901 \\
\cline { 2 - 3 } & Game Strategy $\left(\mathrm{X}_{2}\right)$ & 0.757169 \\
\cline { 2 - 3 } & Motivation $\left(\mathrm{X}_{3}\right)$ & 0.684405 \\
\cline { 2 - 3 } & Technique $\left(\mathrm{X}_{4}\right)$ & 0.780531 \\
\hline
\end{tabular}

Based on the results of the discussion, it can be seen that all the indicators are valid and significant in representing the competence variables of coaches and there is a significant positive influence between the competence of coaches with the competence of character development, motivation competence, technical competence and competence of game strategy.

3) Product Evaluation

The percentage of the coach's description of coach's competence score including $59.69 \%$ of character development competence, motivation competence $55.00 \%$, technical competence $53.51 \%$ and game strategy competence of $50.00 \%$ contains the understanding that the majority of coaches have the same expectations about the competence of coaches covering 4 components that shape it. The value of the evaluation test of the model of structural equation on SEM through PLS (Partial Least Square) is known as follows:

- Measurement Evaluation on Outer Model shows competence of coach $(\mathrm{X})$ consisting of character development competence variable $\left(\mathrm{X}_{1}\right)$, motivation $\left(\mathrm{X}_{2}\right)$, technique $\left(\mathrm{X}_{3}\right)$ and game strategy $\left(\mathrm{X}_{4}\right)$ represented in some indicators, stated valid with value of loading Factor averaged $>0.5$ and reliable with value $>0.7$ and expressed significant with the significance level of $t$ count $>t$ table (1.96).

- Evaluation of Structural Model Analysis (Inner Model) shows the relationship between competence of coach (X) with character development competence $\left(\mathrm{X}_{1}\right)$, motivation $\left(\mathrm{X}_{2}\right)$, technique $\left(\mathrm{X}_{3}\right)$, and game strategy $\left(\mathrm{X}_{4}\right)$ describing all the parameters of the structural model relationship which is significant and has a positive influence on the competence of coaches where the average $\mathrm{t}$-count is greater than t-table (1.96). The data analysis using Smart PLS 2.0 gives $\mathrm{R}$-square value $\left(\mathrm{R}^{2}\right)$ indicating that all indicators in representing competence variable of coach describes significant influence.

Based on the results of quantitative data analysis, the majority of coaches' existence variables have expectations of support from government and related institutions, especially for the sustainability of training competence development and formal legality of the coaches competence. Relevance of government support and related institutions, in this case the association of PSSI, KONI and SSB association can be used as the legal basis of public trust on the coaches.The competence of football coaches for early-aged students has a relationship with and influence on the competence of character development, motivation competence, technical competence and competence of game strategy. The existence of the relationship and influence conceptually gives impact on the competency standard of football coach for early-aged students that are represented by 4 variables and developed into several competence indicators, which can be formulated that competency standard that must be possessed by a coach consists of attitude, knowledge and skill elements.

\section{DISCUSSION}

A. Description of Context Evaluation of Coaches Competency Data and information obtained from some SSB coaches show that the pattern of competence development offootball coaches for early-aged students depicts that its existence requires the legality of support from government and related institutions such as the Association of PSSI, KONI and SSB Association. The existence of coach competencies in development is highly dependent on the performance of coaches in SSB. The mastery and understanding of exercise material is not enough to be a main stay if not accompanied by some other expertise. 
These other skills relate to an understanding of the training method, of the capacity of the trainees he coaches, so that the contents or training materials to be trained are the combined fields of science as the source of the training material intactly required to achieve the targets that the coach has programmed. Studies show that one of the most influential people in sports experience for athletes is the trainer and contextual environment created by coaches [4].

B. Description of Input Evaluation of Coach's Competencies. The coach's human resources should have basic competencies related to coach education. To support the success of coaches in the field, acoach should have a formal education related to the field to be occupied. The average coaches handling SSB have formal education backgrounds ranging from high school to college and the average duration of training is between 5 - 10 years and they have a license qualification as football coach required by the Association of PSSI.It is proven that almost all SSBs have licensed trainers of D and C qualifications. The facts are not enough, of course, since the coach should also improve his ability by following upgrades, training and courses related to the performance requirements of the coach. In general, to improve the knowledge and quality of human resources coaches should master the coaching sciences which are usually provided by SSB associations in their respective areas by organizing relevant, licensed and certified coaching courses.

\section{Description of the Evaluation of Coach Competency} Process

Based on the results of quantitative and qualitative data exposure, the competency standard generated in this research is the performance change of the coaches related to the four components of competence including:

- Character Development Competence

Developing character can be done in various ways, the result of research by Doty showed that character can be taught and studied in sports atmosphere. Exercising can build character, if the environment is structured and there are goals and plans to develop character [5]. Developing character values requires more in-depth study because of several pillars of each character still being developed again based on the character traits. A person of character embodies both character and moral character [6]. Based on the nature, character is divided into two characters namely performanceand moral characters. Rudd and Mondello definitions of character produced two major themes: one related to moral character and the second to social character [7]. The result of the study and analysis in this research is that the value of character on a certain level is done by the coach in order to motivate the students, such as the habit of coaches coming on time to the place of practice, always praying before and after practice, never leaving the practice site before the time. The behavior of the coach reflects discipline and sportsmanship, fair play, and mutual respect.
- Competence Game Strategy

The precision in running a strategy depends on the formation of players who are adapted to the ability and mastery of the basic skills of playing football owned by the players. Strategy is the overall approach that is related with pre-defined planning, while tactics are those that are designed and executed in a game. Strategy refers to the movements needed in a match and its function as a supporter of tactics in the game. Thus, strategy and tactics have different meanings, but in the implementation both terms are interrelated with each other to achieve the same goal of winning the game. Based on field notes and observations, it is found that the coach's depiction at the moment of applying the game strategy of football is strongly influenced by the basics of playing football. The basics of playing football include the skills of playing football, physical condition and knowledge (intelligence and memory) For that a coach is demanded to understandthe game strategy very well, especially to understand the strengths and weaknesses of the opponent, to evaluate each of the results of match strategy applied and to apply variations of strategy to deal with different opponents condition.

- Competence Motivation

The motivation of SSB coaches in the process of coaching the players in SSB is none other than channeling his average hobbies as a former football player, a boost of pleasure, and his own satisfaction so as not to think of the size of the form of rewards received. The role of the coach as a learning agent is a trainer as a facilitator, motivator and inspirator for his students. As a motivator, the coach should be able to generate training motivation for his students by paying attention to the principles of having interest and attention to his work, providing tasks that are easy to understand and rewarding the performance and achievement of his students. From that exposure, the motivation that must be possessed by the coach of early-aged studentsin conducting the learning process in SSB illustrates the things related to the personality of the coachin instilling and helping to build selfconfidence, self-esteem and belief, mental match and sense of togetherness that arise in the coach (internal motivation) without the stimulation or help of others.

- Technical Competence

The ability of coach in game techniques is a very important role and responsibility, because students who are trained are students aged in $8-12$ years which is the golden age. The process of learning in early childhood is a very strategic period of guidance, because early age is the first period in a series of systematic, focused, gradual,, and continuous development of students. In addition, the learning process at an early age is the age where students are first introduced to basic footballing skills that include: feeling with the ball (ball feeling), dribbling, passing, 
stopping the ball (controlling), kicking the ball towards the goal (shooting), heading the ball, attacking, defending, and keeping the goalwell and correctly. Based on this, the coach must have technical competence in the form of basic engineering knowledge of football game which includes understanding and mastery of basic technique of playing football well and correctly so as to enable students to be able to perform and practice some basic football playing techniques taught. Therefore, understanding the basic techniques of playing football needs to be taught to the students as the foundation of the basics of playing football well and correctly.

D. Description of Product Evaluation of Coach Competency A competent trainer is a trainer who can deliver his knowledge to trainees, and demonstrate techniques to them, so that the students can perform the techniques properly and correctly. A competent football coach is a coach who has the ability to compete in accordance with the science of coaching he or she has learned. The competence of football coach for early-aged trainees consist of character development competence, motivation competence, technical competence, and competence of game strategy which are then developed into several competency indicators that must be owned and required. Thus, it can be stated that competence is a statement of what a person should do in the workplace to demonstrate his knowledge, skills and attitudes in accordance with the standards required

The results of the evaluation study, that is the illustration of the competence of football coaches for early-aged students is divided into three elements: 1) Attitudes (affective) that cover character development competence, such as discipline, sportsmanship, fair play, mutual respect, and 2) motivation competence, namely confident, mentally compete, 3 ) skills (psychomotor) which includes the competence of the game strategy (knowing the weakness and strength of the opponent, the strategy of the game, match situation). These three elements are the most basic competencies that must be possessed by football coaches for early-aged students to serve as the foundation of competence standard that include attitudes, knowledge and skills. The results are clarified by Broke \& Stone's opinion in Osman who stated "The essence of understanding of competence so far is to include the mastery of 3 types of abilities, namely: attitude, knowledge and technical skills".

\section{CONCLUSION AND SUGGESTION}

\section{A. Conclusion}

The results of quantitative and qualitative data analysis using CIPP evaluation model consist of:

- The context evaluation of the analysis results states that the existence of the coach who has the legality can be used as the legal basis of public trust on the competence of the trainer.

- The input evaluation of the analysis results state that the background of HR trainers of football coach for early-aged trainees to support their competence should have at least a high educational academic qualification of SMA / SMK / MA, the duration of training experience is 5 to 10 years and should have license D according to authority given PSSI Association. 3. Evaluation process analysis results state that: 1) the character development competence is a very basic foundation in shaping the values of coach personality that must be applied in the learning process of playing football. 2) motivational competence is a motivation that must be owned and developed in the trainees' learning process of playing football . 3) technical competence is the mastery of football playing skills that must be owned by every coach and developed in the learning process of playing football, and 4) the competence of game strategy in learning process of playing football should be able to be appliedand practiced on the field in an actual gameatmosphere.

- Evaluation of product analysis results state that the competence of football coaches for early-aged students has a relationship with and influence on the competence of character development, motivation competence, technical competence and competence of game strategy. The existence of such relationships and influences is a description of the competency standards that a football coach for early-aged students should have. Conceptually, the competency standard of football coaches for early-aged students are represented by 4 variables and developed into a standard competency formulation which is the foundation for football coach for early-aged students in football school (SSB). The standard competence of the coach is conceptually composed of: attitude (affective), knowledge (cognitive), and skill (psychomotor).

\section{B. Suggestion}

Based on the above conclusions, some suggestions that can be presented are as follow:

- The formulation of the competency standards of football coaches, especially those for early-aged students has not yet been formulated or established by the Association of PSSI.Therefore, it needs an instrument to formulate competency standards for football coach for early-aged students which can be applied nationally.

- This research is only done on the football coach of earlyaged students (U-9 sd U-12), so it is necessary to hold research development at the young age level (U-13 sd U20) and for the development of coach competence in other sports that have different characteristics from those of football sport. 


\section{REFERENCES}

[1] Johar Arifin, Kompetensi Pelatih Sepakbola Usia Dini. Berita Sore diambil dari http://www.BinaSepakbola.com. Nopember, 2013.

[2] Philips., Michael BStudent Athlete Perceptions of Head Mens Basket Ball Coaching Competecies at 15 Selected NCAA Division II Cristian Colleges. Murfresboroo: Faculty of Graduate School at Middle Tennesse State University, 2007, hlm. 148.

[3] Sugiyono.Metode Penelitian Pendidikan, Pendekatan Kuantitatif, Kualitatif dan R\&D. Cetakan Ke 14. Bandung: Alfabeta, 2012, hlm. 404

[1] Afta Mylsidayu, Pengembangan Model Tes Keterampilan Bola Basket untuk Anak Usia 10-12 tahun. edisike-13, vol.1, Jurnal IPTEK Olahraga, ISSN:1411-0016, 2011, hlm 1-19.

[2] Armandi John,Kontribusi Motivasi Berprestasi dan Disiplin Kerja Terhadap Kinerja Pelatih, edisi 10, vol. 2, Jurnal IPTEK Olahraga. ISSN:1411-0016, 2008, hlm 97-111.

[3] Asosiasi Sekolah SepakbolaPembinaan Sepakbola Usia Dini (Online Forum Diskusi AS-SSBI) diambil dari http://www.SSB Indonesia.com.Indonesia, , Nopember, 2012.

[4] Bartholomew, K.J., Ntoumanis, N., \& Thogersen, Ntoumanis, C. The Controling Interpersonal Style In A Coaching Contex: Development and Initial Validation of A Psychometric Sclae.,. edisi 32, vol 2, Journal of Sport \& Exercise Psychology, 2010, hlm. 193-216.

[5] Doty Joseph, (2006). Sport Building Character, edisi 7, vol. 3, Journal of College and Character, 2006, hlm. 1-20.

[6] Davidson, Mathew, Developing Performance Character and Moral Character in Youth, The Fourth and Fifth Rs Respect and Responsibility, edisi 10, vol. 2 Journal of College and Character, 2004, hlm.1-6.

[7] Rudd Andy \& Mondello J. Michael., How do College Coaches Define Character A Qualiitative Study with DivisionIA Head Coaches, edisi 7. vol. 3, Journal of College and Character, 2006, hlm. 1-10. 